\title{
Descending and ascending trajectories of dialogical analysis: seventh analytic interpretation on the short story "The guerrillero"
}

\author{
Danilo Silva Guimarães* \\ University of São Paulo, Institute of Psychology. Department of Experimental Psychology. São Paulo, SP, Brazil
}

\begin{abstract}
The dialogical unity for the analysis of the Self includes the descending intersubjective interpenetration of the psychologist's lens into the self-others' feeling/thinking together with the analytic demonstration concerning the transformations of the objects that participate in the intrapsychological stream of the focused feeling/thinking. The theoretical and methodological issues selected for our present study concern how to make dialogical analysis out of empirical data and how to articulate the analyzed content to the interpretative whole situation from which the researcher and the subject matter are part of. Dialogism does not have a standardized procedure and we are not considering that there is only one correct methodological procedure in dialogical psychology. Nevertheless, discussing some dialogical approaches to a short story from Albalucía Ángel (1979), we found that the starting point for the dialogical analysis should be the mediated relation of the Self with the others, emphasizing the relevance of the extra-verbal concrete situation.
\end{abstract}

Keywords: theory and methodology of psychology, empirical data analysis, dialogicality and culture, cultural psychology, semiotic-cultural constructivism.

This study was constructed to attend to a concern of our research group on cultural psychology, at the Institute of Psychology of the University of São Paulo, whose focus is on theoretical and methodological issues in the framework of a semiotic, cultural, and constructivist dialogical psychology. The theoretical and methodological issues selected for our present study concern how to make dialogical analysis out of empirical data and how to articulate the analyzed content to the interpretative whole situation from which the researcher and the subject matter are part of. We are not considering that there is only one correct methodological procedure in dialogical psychology, but our presupposition is that we can learn from previous experiences in order to reflect upon our methodological strategies in the present.

The problem of the dialogical unity of analysis is our starting point to examine some dialogical strategies proposed by a group of researchers that carried out an interactive symposium at the Fifth International Conference for the Dialogical Self, 2008. They presented six approaches for the analysis of a short story by the Colombian writer Albalucía Ángel, "The Guerrillero", originally published in 1979, in her book !Oh Glória Inmarcesible!. Their approaches were synthesized, compared, and discussed, evincing the multivocality of analytic strategies in dialogical science (Wagoner et al., 2011).

From these preliminary efforts to account the complex dynamics of self-positioning, this study will propose an additional possibility for comprehending the subject

* Financing information: CNPq Scholarship of Research Productivity (protocol no. 306563/2013-4).

Corresponding address: danilosg@usp.br matter dialogically. The present analysis considers that the sense of personal identity, such as the feeling of continuity in the stream of consciousness (James, 1890), encompasses a multiplicity of constitutive dimensions derived from concrete social relationships. This refers to the historical and contemporary dimensions comprised in people's lived situation, their phenomenological cultural experiences. These dimensions can become part of the individual Self as a result of lived experiences in the environment which surrounds the person. The articulation between the multiplicity of positions within the Self, in relation with other selves and the socio-historical situation in which something is narrated, is the cornerstone to apprehend the dialogical meaning of the analyzed content.

\section{Bidirectionality and the problem of the unity of analysis in semiotic-cultural constructivism}

Wundt (1912/1924) asserted: "In all psychical combinations the product is not a mere sum of the separate elements that compose such combinations, but [...] represents a new creation". And Koffka (1935/1983) asserted:

It has been said: the whole is more than the sum of its parts. It is more correct to say that the whole is something else than the sum of its parts, because summing is a meaningless procedure, whereas the whole-part relationship is meaningful. (p. 176)

The quarrel about methodological strategies for psychological analysis is not a novelty in our broad field of 
research. It has been present since the very beginning of the constitution of psychology as an independent science, and even before. Researchers that apparently agree with basic general assumptions, such as Wundt and Koffka, above cited, would differ considerably in their methodology of investigation. To take another related instance, Engelman (2002) states that for Wertheimer,

[...] the Gestalten are basically different of what were called sensations at that time. The Gestalten, first perceived, can be decomposed in parts. Nevertheless, the parts are always parts of the former Gestalt. [...] The Gestalt comes before its parts. The determination moves downward, descending and not ascending. (p. 2)

The theoretical and methodological criticism of Wundt's ideas, from the Gestaltist scholars, asserts that instead of starting by the analysis of simple components of psychical life, looking for the laws of association, we should depart from the top, that is, from a holistic perception of the investigated content/process to the identification of its interdependent parts. Then the procedure should be "[...] to find out which parts of nature belong as parts to functional wholes, to discover their position in these wholes, their degree of relative independence, and the articulation of larger wholes into sub-wholes" (Koffka, 1935/1983, p. 22).

Positioning himself concerning the same kind of theoretical and methodological issues, Vygotsky $(1934 / 2001)$ proposes that the investigation of the relation between thinking and language should not depart from the study of isolated functions, but focus on the irreducible relationship between interdependent processes. He distinguished two methods of analysis, one of them fragmenting the investigated complex phenomena into elements and the other circumscribing "the invisible unities which keep the inherent properties of the whole" (Vygotsky, 1934/2001, p. 20). Although a selected object of study can be composed of different elements, the unity of analysis should be the simplest primary shape, which contains the properties of the whole investigated phenomenon.

Additionally, the interdependent relation of elements that constitute unities of analysis is a source of tension. Bringing arguments to justify the meaning of the word as the unity of investigation of linguistic thinking, Vygotsky (1934/2001) asserts: "the transitional process from thinking to language implies a complex process of decomposition of thinking and recomposition into words" (p. 341). Whereas thinking is genetically a diffused whole, the construction of a verbal expression departs from the words to the composed whole. Therefore, thought is restructured when transformed into words:

Precisely because thinking does not coincide with words, neither with the meaning of the words in which they become explicit, the path from thinking to the word passes through the meaning. In our language, there is always a hidden purpose, an occult subtext. (p. 341)

It implies that the full meaning of the word is never achieved, neither by the person who expresses it, nor by the interlocutor who is trying to grasp it. The meaning is a construction that involves the world interpretation of each person, articulated to their internal structure of personality and affective motivation. Finally, the meaning also depends on the zones of sense and stability in which a word takes part. These zones are dynamic: they are socioculturally constructed as well as interpersonally and intrapersonally raised.

The Vygotskian understanding of the process of semiotic-cultural construction of the meanings of words demands a bidirectional methodology, because psychologists should be able to describe the dynamic trajectories of each part of the unity (i.e., thinking and language) in relation to the integrated whole (the verbal thinking). That is, the components of the unity are not fused as an undifferentiated field; it is relevant that psychologists make explicit internal connections between descending and ascending processes.

Therefore, the quarrel between elementarists' and gestaltists' approaches to psychological phenomena could be considered through an integrative psychology, capable of focusing the dialectic tension between processes with distinct identifiable genesis, aiming to elaborate general knowledge (Vygotsky, 1927/1991). The dialectic model, on the other hand, can be understood as a subfamily of dialogical models:

Dialectical models are these formal constructs that define the system in terms of opposition, contradiction, and overcoming of the opposition through a "dialectical leap". It can be seen that all these characteristics are a version of the general focus on relationships between the parts of the system. Furthermore, the specific kinds of contradictory relations and the possibility for the "dialectical" leap need to be defined in dialectical models. Mere statements about the existence of contradiction between $\mathrm{X}$ and non-X (as parts of the system) do not qualify as a formulated dialectical model. The assumption of escalation of the contradictory relationship is necessary, together with the assumption that there exists some (obviously not precisely definable) "breaking point" or threshold for the "dialectical leap" to occur. Without these assumptions, dialectical models do not have any distinctiveness in contrast to other dialogical models. (Valsiner, 1997, p. 159)

In sum, the dialogical unity of analysis is broader than the dialectic unity of analysis because it does not include, necessarily, the teleological presupposition of the synthesis. 


\section{A dialogical unity for the analysis of the self}

The meaning of the word was proposed by Vygotsky as the unity for the analysis of linguistic thinking, including the descending genetic basis of the meaning, i.e., decomposition of the thinking and recomposition in words. But which is the unity of analysis for a dialogical study of the self? The dialogical interaction model (Marková, 1997) presupposes that the elements of a unity are separated, yet remaining as parts of the same whole-inclusive separation-, from which their dynamic tensional relation can be investigated. Dialogism can be applied to understand the relationship between any dynamic communicative system and not only intersubjective processes.

Nevertheless, there are some minimal conditions for a relationship to be dialogical:

Relations among subjects - individual, personal relations: dialogic relations among utterances, ethical relations, and so forth. This also includes all kinds of personified semantic ties. Relations among consciousnesses, truths, mutual influences, apprenticeship, love, hate, falsehood, friendship, respect, reverence, trust, mistrust, and so forth. But if the relations are de-personified (among utterances and styles, with the linguistic approach, and so forth), they change into the first type [object-object relations].

On the other hand, it is possible to personify many object-like relations and transform them into the third type [subject-subject relations]. Reification and personification. (Bakhtin, 1979/1992, pp. 138-139)

Therefore, if A and B are not personal subjectsi.e., psychological functions or voices, objects or social systems-, the elements of a dialogical analysis will be always considered "as if" they were subjects, I-positions, or agencies who actively communicate their perspective, addressing something. Therefore, in any case, the dialogical unity of analysis is the self-other interactions.

Considering that the personified object of study focused on this article is the Self, we should consider it as a situated subject in relation to other personified objects. For James, "[...] a man's Self is the sum total of all that he CAN call his" (1890, p. 291). The idea of sum here presented also implies something else than the "simple sum of parts", because it is based on a process of identity construction:

Our possessions notoriously are perishable facts. The identity the $I$ discovers, as it surveys this long procession, can only be a relative identity, that of a slow shifting in which there is always some common ingredient retained. The commonest element of all, the most uniform, is the possession of the same memories. However different the man may be from the youth, both look back on the same childhood, and call it their own.

Thus identity found by the $I$ in its $m e$ is only a loosely construed thing, an identity 'on the whole', just like that which any outside observer might find in the same assemblage of facts [...]. (James, 1890, pp. 371-372)

The sense of personal identity, as a feeling of continuity in the stream of consciousness, encompasses a multiplicity of constitutive elements derived from concrete social I-other relationships. These elements become part of the self because of lived experiences in the environment that surrounds the person, from the starting to the end of his life. James considers that the presence of the mind is related to the activity of the organism:

The Pursuance of future ends and the choice of means for their attainment are thus the mark and criterion of the presence of mentality in a phenomenon. We all use this test to discriminate between an intelligent and a mechanical performance. We impute no mentality to sticks and stones, because they never seem to move for the sake of anything, but always when pushed, and then indifferently and with no sign of choice. So, we unhesitatingly call them senseless. (James, 1890, p. 8)

The Self belongs to a subject that is active in the world. The determination of the personal action does not come from the natural or social environment although all beings are constrained by the environment. That is, the determination does not descend from the top (i.e., the naturalsocial or mental wholes), nor ascend from the bottom (i.e., the physiological-psychic elements associated). It is from the tension between these distinct trajectories that the Self emerges in its semiotic activity.

Therefore, the internal relations of the Self can be dialogically investigated observing the tension between the constitutive parts of the whole, involving intrapersonal and interpersonal dimensions. For instance, the psychologists' belonging to a cultural field reflects on their appropriation of the expressed feelings and thoughts of someone and considers people's objects of thought as interdependent elements of their analysis. Such first descending approach from the whole I-other relationship to the objects of the other's thinking need to be analytically reversed in order to identify how micro transformations in the stream of otherness' thinking leads to the emergence of novel configurations concerning I-other relationships. In addition, the psychological interpretation happens in a concrete extraverbal situation of dialogical relationship:

In life, verbal discourse is clearly not self-sufficient. It arises out of an extra-verbal pragmatic situation and maintains the closest possible connection with that situation. Moreover, such discourse is directly 
informed by life itself and cannot be divorced from life without losing its import. (Voloshinov, 1926/1976, p. 98)

Therefore, the dialogical unity for the analysis of the self includes the descending intersubjective interpenetration of the psychologist's lens into the self-others feeling/thinking together with the analytic demonstration concerning the transformations of the objects that participate in the intrapsychological stream of the focused feeling/thinking.

Figure 1 shows how the dialogical unity for the analysis of the Self contrasts the path from the Gestaltic perception of the environment to the affective-cognitive elaboration of this perception (internalization, descending path to intrasubjective processes), and the ways a person acts symbolically in order to communicate or achieve something (externalization, ascending path to intersubjective processes).

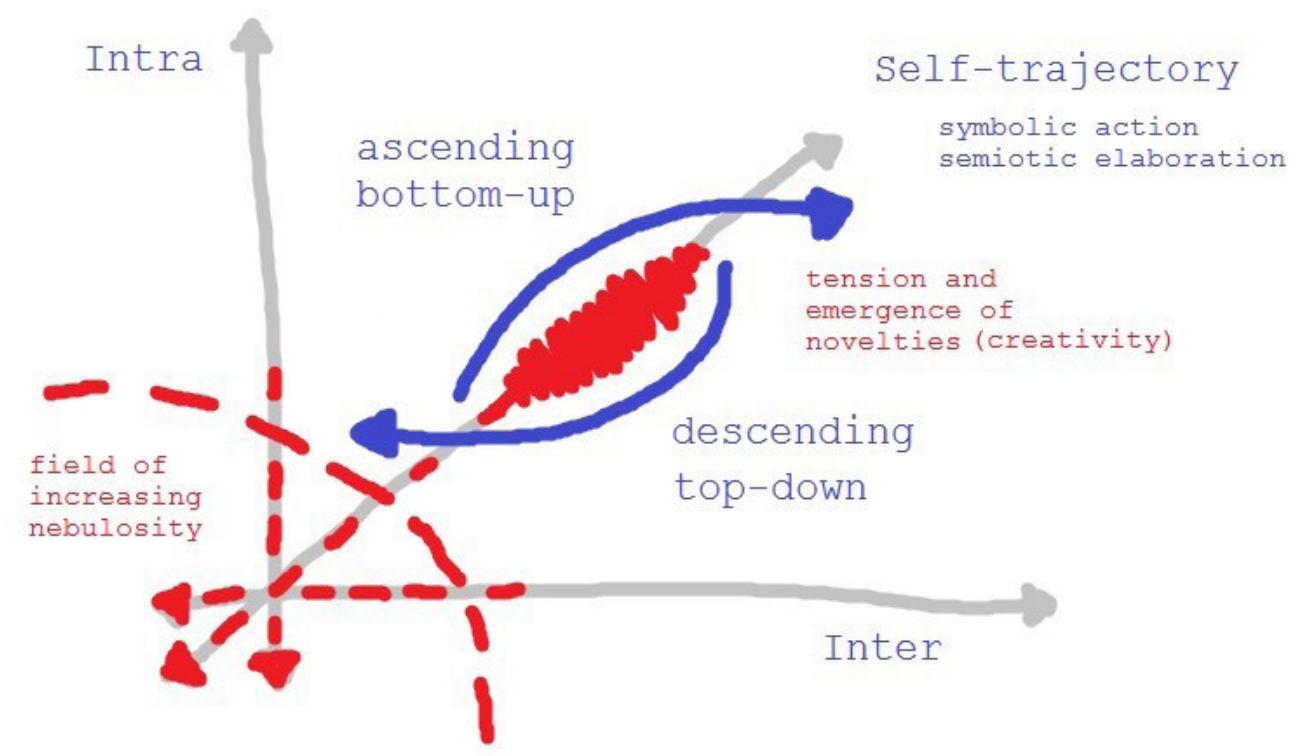

Figure 1. Diagram of ascending and descending processes in the semiotic activity of the Self

\section{How Voices Make I-Positions: a discussion on the variety of dialogical approaches}

The diversity of approaches discussed in the interactive symposium "How Voices Make I Positions - An Exercise in Collective Investigation", convened by professor Livia Mathias Simão (IP-USP) at the Fifth International Conference for the Dialogical Self, 2008, indicates that dialogism does not have a standardized procedure. Although some researchers have made efforts to systematize the adopted methodology, in order to make it generalizable to future analyses of diverse contents, it does not mean that these approaches are the final word concerning dialogical analysis, even for their proponents.

The following aspects from each presented paper were selected: 1) the object taken into consideration for the analysis; 2) the descending trajectory of analysis, from a holistic view of the object to the discrimination of the parts belonging to the whole; 3 ) the ascending trajectory of analysis, from the approach of the text elements to its integration into the whole meaning of the story; 4) the general considerations that emerged as a result of the non-coincidence between the initial whole perception and the subsequent analytical presentation of the object.

Gillespie's (2008) interpretative analysis considered the text as a snapshot of Felicidad Mosquera's thought at a particular moment: a stream of memories, thoughts, selfrapprochements and future fears, or a stream of thoughts. From the four characteristics of a stream of thought: changing in continuity; relation with objects; selective attention; and private content, the author searched semiotic mediations overcoming an action block, rupture guiding shifts of perspective of the story's character. Then, data were coded, identifying all the active characters and I-positions as components of the Self. These I-positions were categorized in terms of the "I", "Me", and "other", and those who were identified as changing during the course of the narrative were selected for the analysis. Plotting the temporal movement of the stream of thought: rupture, lament, realization, resolution, and self-regulation, Gillespie (2008) identified the role of the internalized others in his dialogical analysis of Felicidad's Self. He concludes that not only I/Me dynamics are essential to understand the dialogical stream, but the others within-self are also essential. The stream 
of thoughts begins with a thought attributed to others and reaches its major turning point also in the thoughts attributed to others.

Salgado (2008) approached the text as the narrator telling Felicidad Mosquera the dangers she is facing in an almost threatening way in order to warn her, in an undetermined location, but involving South American guerrillas. From the overall context involved in the situation, he defined the unity of analysis as the response units: grammatical sentences, independent or main clauses. Then, general parameters to analyze each unity were defined: who, to whom, what, how, and why. From 79 identified unities, Salgado (2008) categorized each sentence according to identified I-positions (i.e., warning, reproaching, recalling, blaming, accepting, encouraging). Finally, he constructed a table, a graphic, and a descriptive text to show the development of these several positions throughout time. From this procedure, he was able to interpret the feeling tone in the text, observe where ruptures leading to changes in the feeling tone took place in the dynamics of the narrative, and comprehend inner spaces as spaces of alterity, because discontinuities between the agent and the addressee create the space of dialogical negotiation and change.

Simão (2008) selected for the analysis the character's Self-Other relationship, focusing the relation of selected aspects of the short story with philosophical and meta-theoretical issues of psychology, such as the meaning of happiness ("Felicidad" means "happiness" in Spanish). She identified expressed ambiguities (impotence and internal rebellion) in the narrative and the active processes in relation to the ambiguities (perseverant remembering, pervasive revival of Felicidad's intensely happy past moments). Then, Simão (2008) observed in the text utterances of unexpected experiences that implied a transformative process (the Guerrillero's arrival bringing happiness, such happiness producing a continuity in the internal relationship Self-other). The resulting internal chaotic polyphony of Felicidad's mind (contrasting voices about herself and the other) guides the emergence of a new and coherent view about herself in the relation with the other in the present. This process was articulated with general conceptions discussed in hermeneutic philosophy (cf. Gadamer, 1959/1985; 1966/1976): the relation with the alterity; the experience of negativity; the enlargement of horizons. Finally, the feeling tone of the narrative was linked with some contextual dimension related to it (to be illusioned). Simão concluded: the duality between reality and unreality, imaginary anticipation of the future due to the relation with otherness' voices creates expectancies. Past and future experiences are articulated in the present, guiding the action potential (Boesch, 1991) of the person, producing misunderstandings and transformations.

Valsiner's (2008) interpretative analysis selected the realities of love of Felicidad Mosquera, identifying the "bare story" narrated in a particular way, that is, the short story presents the flow of an ordinary encounter of Her and Him (the Guerrillero), a regular structure of a meeting that is not relevant to his analysis. The signals of Self-reflexivity in the relation between external and internal events, the movements of objectivation and/ or subjectivation of the Self (actual other people who reflect upon the person) were focused to find the marks of irreversible change in the Self (generalized I-positions). He showed how I-position moves between subjective and objective perspectives, constructing a schema of the recursive process, concerning actual other people who reflect upon the person. Mapping the distinction within irreversible time in the utterances presented in the text, Valsiner (2008) elaborated a second schema of a recursive process, which includes the first schema (generalized I-positions). Concluding: the I-positions can move rapidly in a flow that feeds the dynamic system of the self in two levels (related to two kinds of "social others"): one of them is the externalized and generalized I-positions; the second concerns the actual other people who reflect upon the person.

Wagoner (2008) approached the story as a stream of conscious reflection on the character's situation; an emotionally loaded dialogue with herself. From the selection of external I-positions speaking to internal I-positions, the repositioning of the I-positions, he identified the emotions that arise and stabilize in reflection. He focused the boundaries of the emotions, how they are linked to particular exchanges among I-positions in the transition to another emotion. To make it evident, Wagoner (2008) found how, in certain parts of the text, sentences seal the link between past events, consequences, and the futurity of the Self. The emotion expressed in the organization of these temporal links in the narrative (i.e., fear, regret, romantic love, return to fear, spiritual ecstasy, courage) guided innovative shifts in the Self-evaluation of the experience in time in the flow of the narrative. Emotions are intrinsically related to our experience of temporality (past, present, and future), articulated with voices we have contact with in our personal history within the cultural context. The feeling tone of the narrative was, then, articulated with some contextual dimension related to it (i.e., the meaning of Felicidad as courageous happiness).

Finally, Zittoun (2008) interpreted the short fictional text as a monologue from Felicidad Mosquera, considered as if it were "real", a free flow of thinking/speaking, mediated by language, then she considered the relation of the narrator addressed to a "you", both parts of the same person, which evolves inducing transformations in each component of the relation. Analytic dimensions were built, such as the (social) position of the narrator, the time-space of the scene, the degree of reality (what happened is real or imaginary) and the degree of distancing (from the semiotic means used to mediate experiences). Then, psychological ruptures became identifiable in the text. Zittoun (2008) analyzed the text first finding contrastive, opposed utterances and/or utterances denoting a conflict, articulating them to the temporal dynamics of transition from a rupture (changing of subjective relational positions). Then, the 
main movements of the text were identified and labeled: They'll arrive; If-only; Hosting the Guerrillero; They're coming; But only God and you are witnesses; And who's to judge you... Not a whisper; Don't look like that... Hold their eyes. The semiotic operators of change were also categorized as the Pre-symbolic overwhelming feeling tone; This could be; Emergence of a field of an imaginary BadDevil; Advancing to a field of imaginary short-circuit; Articulation with inner experiences; Emergence of a field of Holy; Resignification of initial situation. Finally she constructed a graphic showing the dynamics of change, summarizing the moments of semiotic elaboration of the personal sense of the rupture, and emphasized that the transition process that brings from one position to another is a semiotic elaboration.

From the analysis presented in the symposium, we can observe that these dialogical approaches are concerned with dynamic processes that imply semiotic elaborations of affective experiences within the Self, the emergence and change of feelings through personal active reflection in time. The methodology of analysis consists in the identification of ruptures or shifts of perspective expressed by the person in relation to the I, others, and/or the world. Some of these shifts can be more or less relevant to the person, and the construction of a map on the Self-movements can be useful to describe it. Additionally, it is possible to observe that the particular analyzed case can be viewed as an instance of general existential issues of human beings, at the same time that a microgenetic analysis of the utterances shows the singularity of the lived situation narrated in the short story. An important issue to interpret the feeling tone of the utterance and its ruptures in the dynamic process depends on the articulation of how the person perceives what occurred in the past (immediate and/or distant) and how he/ she articulates it to expectancies of the future (immediate and/or distant).

Although the relevance of the extra-verbal context of the analyzed situation has been mentioned a few times, this was not really the focus of the analysis. Sometimes it was taken for granted, in others, some contextual historical or linguistic dimensions were plucked out in order to corroborate the main argument of the researcher. Additionally, in the process of generalization of the ideas that emerged from the analysis, some articulations with philosophical presuppositions were also proposed. Nevertheless, predominantly, the analysis remained restricted to the verbalized content.

\section{A seventh dialogical approach to the short story: the researcher and the work of art}

Human actions and their objects are symbolic (Boesch, 1991, 1997), that is, all perceived reality has subjective connotation. The psychological meanings are related to the phenomenological field of experience a singular person constructs with the environment, in which some other people are relevant. People act while experiencing their surroundings, transforming the lived situation in some degree and direction. The work of art is one kind of expression of such symbolism. It materializes the creative gesture of one or more than one person, who articulates sensible elements in the composition of meaningful shapes (Langer, 1953). Such shapes sediment a set of feelings organized by the author(s) in a communicative process. The notion of feeling I am referring to relates to the selective interpretation of ideas from Stern, by Josephs (2000):

Feeling is a mode of relating to one's internal or external world. We feel in a certain way with regard to somebody or something or ourselves. Feeling is a dynamic process located in the feeling person, sometimes salient, powerful and overwhelming, sometimes hidden in the background; sometimes fuzzy and not easy - or even impossible - to verbalize, sometimes clearly framed and categorized within the language of feeling and emotion. This process can lead either to the transformation or to the maintenance of our present relationship to the world and to ourselves. (p. 815)

From this perspective, affect and cognition are not strictly separated; on the contrary, the cognition is something that allows the distinction of emerging feelings from an affective-nebulous plan that permeates our experience in the world. The language as other affectivecognitive elaborated cultural utterances constrains the affective-nebulous plane, guiding the process of sharing meanings with others. Those who communicate creatively use diverse devices in order to compose a shape (i.e., auditory, visual, tactile etc.) that guides the attention of the interlocutor to the sensible intellectual sphere of the desired utterance.

A cultural product, therefore, does not express only the feelings of the author, but intervenes in a world where the interlocutors (or the spectators) are living. The symbolic action or production of a symbolic object can emerge as an effort to converging perspectives, in which authors deploy the product of their work to someone (the interlocutor). Therefore, the cultural product is a consequence of the active organization of the feelings of the author in a communicative process involving a communicative situation with other people. The active organized work - the product has a structural dimension, but it is usually openended, accepting the multiple meanings of whoever enters in contact with it.

From this perspective, the symbolic cultural objects can be understood as sediments of the intersubjective stream of feelings (Guimarães, 2010), a consequent exchange between the author, who worked in the production of an objective utterance, and the interlocutors, the public of an art work, for instance. We can summarize this in the following diagram of dialogical and recursive relating processes: 


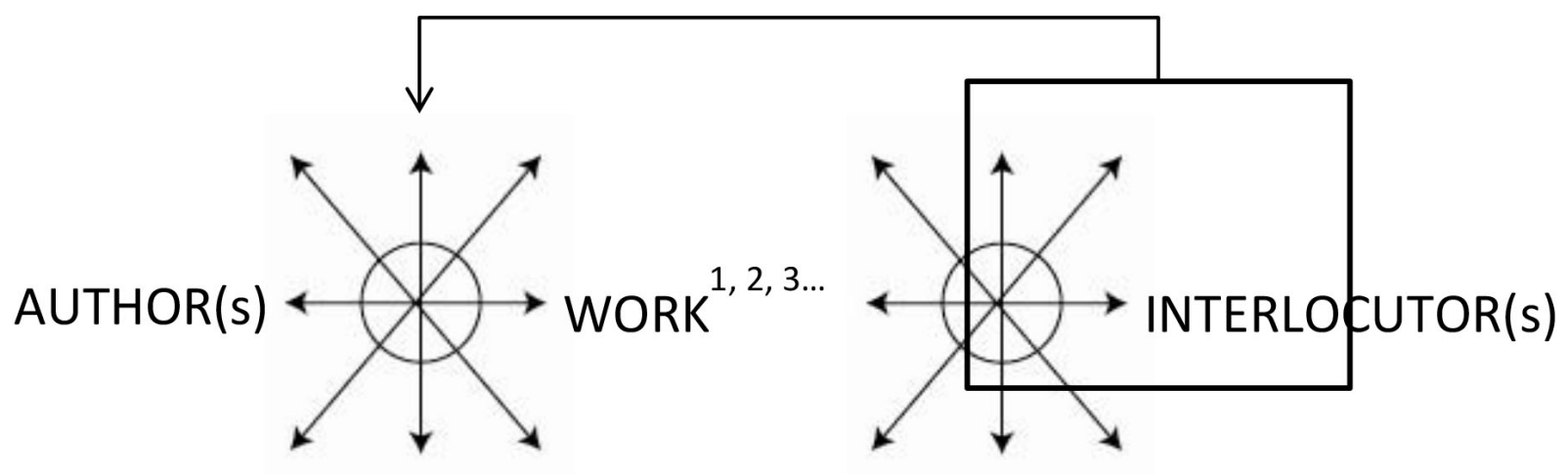

Figure 2. Intersubjective flow of feelings leading to symbolic elaborations through constructive work on cultural objects (adapted from Guimarães, 2010)

Figure 2 is a diagram to show the path of the elaboration of symbolic objects (as the work of art) from the creative organization of feelings. Some of the interlocutors' answers after the reception of the work also affect the authors, who can use this experience reflexively as an element to guide their novel productions. For instance, the reception can frustrate or disquiet the authors, demanding some affective reorganization with an eventual novel aesthetic result. Of course, some of these impacts are never reflected in the work and the authors are not always aware of the influences that guide their work.

When a book is published, it becomes an object relatively independent of the author. Even though the name of the author is signed in the book, its meaning is opened to the diverse possible interpretations of the readers. Authors intervene in a sociocultural field, but do not have the control of the effects of their work in the same field.

\section{Descending trajectory on the dialogical analysis of "The Guerrillero"}

The foothold was taking the focused object (the published short story) as a work of art, as a symbolic object emerged from the relation between the author and the readers. This presupposition is based on the dialogical irreducibility of the speaker, what is being said, to whom something is being said, and when it is happening (Wertsch, 1993; Simão, 2003). First, we need to consider that the whole situation involves us, as researchers, looking at the work and expressing something about it in the present. Then, we can notice that the work is a cultural object that also has an author who expressed something in a concrete situation. The second step is, therefore, to focus on the irreducible whole of the short story as a dialogical work within a social context.

The author of "The Guerrillero" (1979), Albalucía Ángel (1939-), is a Colombian writer. To be Colombian and to be a writer puts her in a doubly challenging position: as a woman, she subverted the normative gender roles placing the woman in the position of writing her own history, guiding her life. As a Latin-American, she also subverted the precarious condition historically imposed on these peoples, as exporters of raw material, showing the world the dignity of a people that is also able to make valuable art. As we will see, Felicidad Mosquera, the main character of the story, also actively produced a shift as a woman that resists the oppression she faces in her land.

Differently from the main character of the story, Albalucía Angel, the writer, was born in a family from the upper classes, of coffee farm owners. She studied in the expensive University of Los Andes (Bogotá) before going to Paris and Rome to continue her studies. During the seventies, when the story was written, she was constantly moving between Europe and Colombia and finally, in the eighties she moved to United Kingdom, where she ministered conferences concerning feminist issues. She was married with the Chilean writer Mauricio Wacque and divorced some years after. As we can notice, the gender issue is relevant to the author. As it will be evinced in our dialogical interpretative analysis, the character Felicidad Mosquera expresses a struggle for resistance carried out by the main character.

In the seventies, Albalucía Ángel was concerned with social issues from Colombia, this is especially visible in her effort to recover childhood memories, when she lived the period known as "La violencia" (Williams, 1990). Many Colombian writers focused this disquieting historical period in novels (cf. Osorio, 2006; Cedeño \& Nolla, 2008; González, 2009). Thus, it is possible to interpret that the book and the short story are a contribution to a broader dialogue with her colleagues, fellow country citizens and other peoples about the issue of violence. The affective experience of temporality, in which "The Guerrillero" takes part, links the writer's childhood to a contemporaneous dialogue of local and universal relevance.

The short story denounces the precariousness of life in Colombia. The book in which it was published invites us to overcome the superficiality of a touristic sightseeing to perceive different spectrums of the violence that sometimes appears subtly and many times crudely. The epigraph of the book refers to a letter of H. Rojas Herazo to Pablo 
Neruda, and says, "That's Colombia, Pablo". If we consider the title of the main sections of the book (1. Sightseeing in the Valley; 2. Souvenir from San Adres; 3. Outumn Landscape; 4. Postals from Boyaca and a little Picture in Santa Fé; 5. Stencils of Guerrilla - our short story is here; 6. Make a trip to Choco and pay after; 7. Tour across the Caribbean coast; 8 . Various flashes), we can clearly perceive an irony: the book sections remind a tourist guide, showing an almost playful experience of the land, but the content of the stories shows the contrary, the tribulations of those who live there.

Now we need to go a step further in our descending trajectory of analysis to focus on the irreducibility of the speaker, what is being said, to whom something is being said and when it is happening within the short story. The main character, Felicidad Mosquera, lives alone, in a rural area of Colombia that faces an armed conflict. The narrative seems to be a stream of thoughts that starts after the Guerrillero has left the house of Felicidad Mosquera. It indicates that they had a fast though strong affective relationship and that apparently she fell in love with him. Her dialogue brings some memories of the recent experiences, including some of her experienced feelings with the Guerrillero; she also makes reference to God, as if some of her thoughts had become a prayer; and her concern with what would happen when the soldiers arrive. It is possible to observe a transformation from the initial expression of fear, abandonment, and submission in relation to the oppressors to an expression of self-confidence, self-acceptance, and insubordination through silence. The short story is concluded with the following "Open the door yourself. Stand upright in the doorway. Hold their eyes".

\section{Ascending trajectory on the dialogical analysis of "The Guerrillero"}

The ascending trajectory will be accomplished here with a selective observation of the expressive aspect of the utterances as "the speaker's emotional evaluation of the referentially semantic content" (Wertsch, 1993, p. 108). This observation is guided by the elements assumed as relevant after the primary descending trajectory. From the previous steps, it was possible to assume that the meeting with the Guerrillero fed the reflexivity of Felicidad, reorganizing some of her previously structured systems of references. But how did it happen? To understand this process, I propose to look attentively at four dialogical oppositions underlying the first half of the short story:

\section{A. Conservative X Liberals:}

Now you'll see, Felicidad Mosquera, when they all arrive with their machetes, threatening, asking you where in hell has he hidden himself, then you'll confess. ... Don't curse anymore: he's far away and all that counts is that he lives and carries on fighting. (Ángel, 1979/1986, p. 119)
This selected excerpt presents the historical armed conflict between political positions in Colombia. Nevertheless, the short story will not explore this opposition at the level of political debate, but focus on possible implications to interpersonal affectionate relationships.

\section{B. Care X Violence:}

That night, when Sebastian Martinez's dogs began to howl as if they'd smelled the devil, and you saw him there, suddenly, standing ever so still, his trousers in shreds and his white shirt all bloody, then you should have spoken, said anything, any excuse to make him whisper good-night and creep back where he'd come from, but no, too bad it didn't happen that way. Bad luck, Felicidad. You made him come without a word, you pulled up a chair for him, he let himself fall heavy as lead, and then you saw the other wound on his skull; I'm tired, was all he mumbled; and then collapsed like a horse on the floor. (Ángel, 1979/1986, p. 119)

Felicidad unexpectedly faced the Guerrilero and could not avoid her impetus to take care of him, as he was wounded. The experience of care lived with the Guerrillero is contrasted with the expectancy of violence from his opponents.

\section{Sins X Decency:}

Whatever got into your head, Felicidad Mosquera? What evil star dazzled you then, what evil wind blew through your heart to stir up the fire, to blind you? Because you were blind, blind. The shivers you felt when you looked upon his face and realized he was so handsome. That you liked his black moustache. The nervous urgency with which you went to boil water and prepare the herb plasters, somehow wasn't yours. Because you've always been coolheaded. A watchful heart. You never let yourself be trapped into these things. (Ángel, 1979/1986, p. 119)

The excerpt remarks the erotism that emerged in meeting with the Guerrillero, contrasting with the usual circumspection of Felicidad Mosquera. The emerged feelings were unexpected to her, creating conflict to her self-identity.

\section{Subjected woman X Oppressive man:}

They'll force you to betray him because if you won't talk they'll take the old folks, like they did two days ago with your friend Cleta, remember, or they'll put your hands into the fire, like Calixta Peñalosa, or they'll slice open your belly, after all-all of them- have used your body. (Ángel, 1979/1986, p. 119) 
The issue of violence resonates in a gender issue. However, the way the Guerrillero meets Felicidad inverts the poles of an asymmetric relation: he is a man who appears more fragile than she; he asks her for help. His inverted position creates a surprise. Instead of danger, his fragile aspect guides her feelings first to an ethical affection, and next to an erotic involvement. The disquieting experience demands reorganizations in the affective-cognitive dialogically structured pre-conceptions of Felicidad.

\section{Felicidad meets the Guerrillero...}

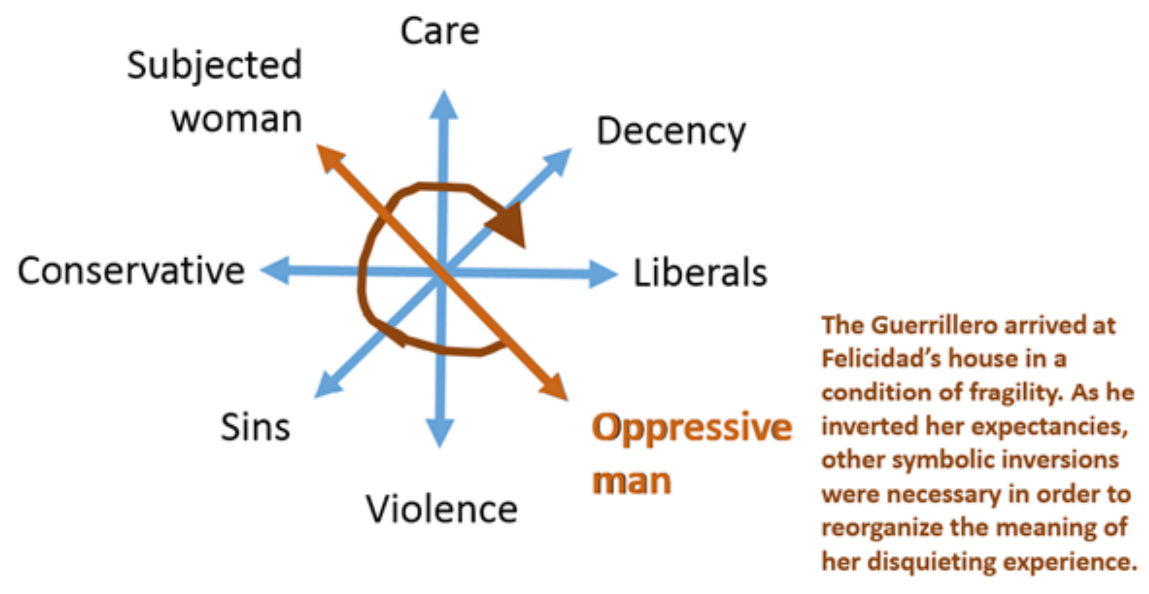

Figure 3. Dialogically structured field ruptured transforming the affective-cognitive preconceptions of Felicidad

Her conflict is also linked to the judgment of an internalized external observer. She lived a secret experience that only God, as an omnipresent and omniscient being, could know. Nevertheless, in this case, she concludes that He would have compassion, and starts to feel that she was right in her attitudes, she is convinced she lived an authentic love!

They'll say they know so that you go for it. But only God and you are witnesses. The only witnesses of the meeting in the field, on the river bank, between the scented sheets; who else will swear if only you felt the delight, the sex entering you into streams, twilight, sea; who else will know the movement of your thighs, burning, your hands searching; touching the groin forcing sweetly your way into life. Who else heard his groans. His loving search. His long, drawn-out orgasm as you sank into a silence of moist membranes, a quick throb of blood, a hurried quiver of muscles, which then relaxed rippling through the entire body, an inside scream bursting upwards, like a torrent. And who's to judge you, Felicidad Mosquera, if only God and you can swear that this is true. (Ángel, 1979/1986, pp. 120-121)

1 This issue can be articulated to the new left conception of free love in opposition to the traditional marriage. Some implications of this conflict to the Self-identity was discussed before (Guimarães, 2013), based on a clinical report from Ernst Boesch (1991).

2 Also in the sense of legitimacy, from the Spanish version “... si sólo Dios y tu pueden jurar que eso fue cierto” (Ángel, 1979, p. 118).
I consider that there are at least three dimensions of self-reorganizations of the main character after her disquieting experience. First, she accepted to take care of the Guerrillero instead of regretting it. Second, she accepted her unbridled passion. Third, she became proud, an energetic woman. Felicidad does not regret anymore, she does not condemn herself morally, and chose to not betray her lover, even though he abandoned her.

No one will dare. They can search your very innards, cut you into two with their machetes, drill into your senses, pierce your heart, they will find nothing. Not a whisper. Don't look like that. Throw your fear overboard. Don't curse any more: he's far away and all that counts is that he lives and carries on fighting. You won't say a word. Not even if they set fire to your shack, ram themselves into you, or bottles, or do what they did to others to drive you crazy; take courage, Felicidad Mosquera, don't cry or moan anymore. Open the door yourself. Stand upright in the doorway. Hold their eyes. (Ángel, 1979/1986, p. 121)

Felicidad decides not to accept the violent oppression she associates with the opponents of the Guerrillero. Nevertheless, her resistance does not presuppose a combative, aggressive posture. It is a silent resistance, that cannot be associated with passivity (Rocha, 2004), but as it is, it can be considered as a strategy to assume the control over 
the situation by the means of privacy. In convergence with it, Felicidad also chose not to follow the Guerrillero.

The emergence of God in the narrative characterizes the tie of Felicidad with a deep personal experience that structures her Self, actions, and conceptions in face of the lived. Such Christian structuration polarizes the world through goodness and evilness categories, which operates in the expected destiny of the character. As she is tied with God, she can hold her eyes and stand upright in the doorway where the oppressors will come. We can suppose that if she had left with the Guerrillero, she would not call for God, because her destiny would be in her hands or in the hands of her lover.

However, Felicidad's God is peculiar: He does not consider her erotic-amorous aspirations and experiences a sin, but legitimates them as something authentic.

From the short story to theoretical reflections concerning the dialogical development of the Self, I think that the meaning of the personal experience is linked to the mythical background that constrains the ideological, aesthetic, affective-cognitive apprehension of reality (cf. Boesch, 1984). Each person internalizes the mythological conceptions of truth from a singular perspective that structures the personal evaluation of possibilities and limits for acting in the world. Nevertheless, the meeting with other people, experienced as a relation with alterity, allows the rupturing of solidified preconceptions, providing the opportunity for reflection and novel symbolic elaborations.

\section{Final considerations}

From what we discussed here, I would like to emphasize with Voloshinov (1926/1976) that the starting point for a dialogical analysis is not the consciousness as a stream of thoughts, but the mediated relation between the Self and the others that happens in an extra-verbal concrete situation. Then, I follow the Vygotskian principle according to which, in the communicative situation, thinking as a whole is decomposed and recomposed in a dual process that creates tension. Considering that our perception works from the apprehension of the Gestalt to its decomposition into interdependent parts, communication also depends on the organization of linguistic elements into a composed whole that is also relevant. To understand this dual process, I used the contrast between the descending trajectory of perception and thinking (internalization of the intersubjective process) and the ascending trajectory of communicating and acting (externalization of intrasubjective process). I propose that this contrast can be a methodological device to identify the relevant tensions for dialogical interpretative analysis.

The present effort to achieve some methodological principles in the framework of the semiotic-cultural constructivism in psychology has left some issues without an answer. For instance, I did not define enough where is most appropriate to circumscribe the analytical focus, that is, in the descending trajectory of analysis (top-down), where can we localize the "top" boundary? And in the ascending trajectory (bottom-up), what need to be considered as the bottom boundary? In the selected case of the short story analysis, the irreducible "who-says-what-to-whom-when" could be approached considering more and more information about the biography of the author and the social-historical context of the work production. Certainly, a Colombian reader would have much more elements to sophisticate my interpretation, including detailed information about many references that are present in the book of Albalucía Ángel (1979). In any case, people who are conducting the analysis will always be selective in the definition of the dimensions that compose their baseline for interpreting. However, to make this baseline explicit is a relevant task to construct argumentative consistency.

The ascending trajectory divide the text analytically according to its utterances as grammatical sentences, or, alternatively, we could have made an analysis focusing the proper construction of each utterance, observing, for instance, the selected words in the construction of the phrase denoting emotions (such as Wagoner, 2008), ruptures (such as Zittoun, 2008), or pronouns. What is relevant to focus in the ascendant trajectory is, somehow, constrained by the general ideas emerged in the descendent trajectory and in general presuppositions of the researcher concerning the problem of investigation. Then, if we are considering that emotions are relevant to understand the dialogical Self, the words or utterances in which it is being expressed will be selected for the analysis; but if the most important is the developmental trajectory in which the Self is transformed, it will be relevant to focus on signals of rupture and the movement of personal transition. If the Self-other relationship is the main issue to be focused, then the references to otherness and selfness will be selected from the analyzed material. Therefore, a good theoretical introduction concerning the object of study and the main concepts of the framework is essential to justify the bottom boundary of the ascending trajectory.

Finally, from the interpretative analysis here proposed, I would like to emphasize the role of the non-shared dimensions of the dialogue. The conception that "there is always in our language a hidden purpose, an occult subtext" (Vygotsky, 1934/2001, p. 341), because thinking does not coincide with the word, suggests that there is also a non-coincidence between the descending and the ascending trajectory of analysis. I am proposing here that between the trajectories of dialogical analysis there is a gap that needs to be fulfilled by who is presenting the analysis. In this sense, the process is, at the same time, analytic, fragmenting the whole into smaller parts, and interpretative, creatively reorganizing the meaning of the content into a new whole shape. The non-shared dimensions of the dialogue allow a creative immersion in the communicative process. Additionally, we can notice another dimension related to non-sharing. The silence of Felicidad Mosquera protects her from sharing private experiences with people who could threaten her because of these experiences. In this sense, non-sharing is a way of Self-protection that 
emancipates the person from possible injuries of the environment. The dialogical restriction of the full access of otherness inwards meanings indicates that the alterity of the other is fundamental for the psychological development, essential to the maintenance of a creative answerability in the self-other relationship.

Acknowledgements: The production of this text was funded by CNPq (476521/2013-0)

\section{Trajetórias descendentes e ascendentes de análises dialógicas: sétima interpretação analítica de o conto "O Guerrilheiro"}

Resumo: A unidade dialógica para a análise do Self inclui a interpenetração intersubjetiva descendente a partir das lentes do psicólogo sobre os sentimentos/pensamentos presentes na relação Eu-Outro, juntamente com uma demonstração analítica que se volta às transformações dos objetos que participam do fluxo intrapsicológico de pensamentos/sentimentos focalizados. As questões teórico-metodológicas selecionadas para o presente estudo concernem a prática dialógico-analítica de dados empíricos e a articulação do conteúdo analisado ao todo da situação da qual pesquisador e tema de pesquisa são partes. $\mathrm{O}$ dialogismo não possui um procedimento padronizado e não estamos considerando que exista apenas um procedimento metodológico correto na área. No entanto, discutindo algumas abordagens dialógicas ao conto de Albalucía Ángel (1979), encontramos que o ponto de partida das análises dialógicas deveria ser a relação mediada do Self com os outros, enfatizando a relevância da situação extra-verbal concreta.

Palavras-chave: teoria e metodologia da psicologia, análise de dados empíricos, dialogicidade e cultura, psicologia cultural, construtivismo semiótico-cultural.

\section{Trajectoires descendantes et ascendantes de l'analyse dialogique: septième interprétation analytique de le conte "Le guérillero"}

Résumé: L'unité dialogique pour l'analyse du Soi comprend l'interpénétration intersubjective originaire du regard du psychologue sur les sentiments/pensées présents dans la relation Moi-Autrui, et la démonstration analytique effectuée à partir de la transformation des objets qui participent au flux intra-psychologique du sentiment/pensée focalisé. Les questions théoriques et méthodologiques choisies pour notre étude concernent la pratique dialogico-analytique des données empiriques, et l'articulation du contenu analysé avec l'ensemble de la situation interprétative dont font partie le chercheur et le sujet. L'interprétation dialogique n'est pas une méthode standardisée et ne se limite pas à une seule procédure méthodologique en psychologie dialogique. Toutefois, en regardant de près les approches dialogiques du conte d'Albalucía Ángel (1979), nous constatons que le point de départ de l'analyse doit être la relation de médiation entre le Soi et les Autres, soulignant que nous devons mettre l'accent sur l'importance de la situation extra-verbale.

Mots-clés: théorie et la méthodologie de la psychologie, analyse des données empiriques, dialogicalité et culture, pychologie culturel, constructivisme sémiotique culturel.

\section{Trayectorias descendientes y ascendentes del análisis dialógico: séptima interpretación analítica del cuento "El guerrillero"}

Resumen: La unidad dialógica para el análisis del Self incluye la interpenetración intersubjetiva desde la mirada del psicólogo sobre los sentimientos/pensamientos presentes en la relación Yo-Otro, junto con una demostración analítica que se centra en las transformaciones de los objetos participantes en el flujo intrapsicológico del pensamiento/sentimiento enfocado. Para este estudio, los temas teóricos y metodológicos seleccionados para nuestro presente estudio enfocan la práctica dialógica y analítica de datos empíricos, así como la articulación de los contenidos evaluados con la situación interpretativa que forman parte el investigador y el objeto. El dialogismo no tiene un procedimiento estandarizado, tampoco consideramos que hay solamente un procedimiento metodológico adecuado en psicología dialógica. Sin embargo, cuando observamos enfoques dialógicos en el "El guerrillero", cuento de Albalucía Ángel (1979), encontramos que el punto de partida para el análisis dialógico debe ser la relación mediada del Self con los otros enfatizando la relevancia de la situación concreta extraverbal.

Palabras clave: teoría y metodología de la psicología, análisis de los datos empíricos, diálogos y cultura, psicología cultural, constructivismo semiótico-cultural. 


\section{References}

Ángel, A. (1979). ¡Oh, gloria inmarcesible! Bogotá, Colômbia: Instituto Colombiano de Cultura.

Bakhtin, M. M. (1992). Estética da criação verbal. São Paulo, SP: Martins Fontes. (Trabalho original publicado em 1979)

Boesch, E. E. (1991). Symbolic action theory and cultural psychology. Berlin, Germany: Springer.

Boesch, E. E. (1997). Reasons for a symbolic concept of action. Culture \& Psychology, 3(3), 423-431.

Cedeño, J., \& Nolla, M. V. (2008). Violentamente Colombia. Revista Iberoamericana, 223(74), 333-341.

Engelmann, A. (2002). A psicologia da Gestalt e a ciência empírica contemporânea. Psicologia: Teoria $e$ Pesquisa, 18(1), 1-16.

Gadamer, H.-G. (1976). The Universality of the Hermenutical problem. In D. E. Linge (Ed.), Philosophical hermeneutics (pp. 3-17). Berkeley, CA: University of California Press. (Trabalho original publicado em 1966)

Gadamer, H.-G. (1985). Truth and method. New York, NY: Lexington. (Trabalho original publicado em 1959)

Gillespie, A. (2008, August). The guerrillero: a dialogical analysis. Paper presented at The 5th International Conference for the Dialogical Self, Cambridge, UK.

González, M. M. (2009). La violencia e el narcotráfico en la literatura colombiana. Cadernos de Postgrado, 3, 121-167.

Guimarães, D. S. (2010). Symbolic objects as sediments of the intersubjective stream of feelings. Integrative Psychological \& Behavioral Science, 44(3), 208-216.

Guimarães, D. S. (2013). Self and dialogical multiplication. Interacções, 24(9), 214-242.

James, W. (1890). The principles of psychology. New York, NY: Holt.

Josephs, I. E. (2000). Feeling as movement from a personcentered standpoint: going beyond William Stern. Theory \& Psychology, 10(6), 815-829.

Koffka, K. (1983). Princípios de psicologia da Gestalt (Á. Cabral, trad.). São Paulo: Cultrix. (Trabalho original publicado em 1935)

Langer, S. K. (1953). Feeling and form: a theory of art. New York, NY: Scribner's.

Marková, I. (1997). On two concepts of interaction. In M. Grossen, \& B. Py, Pratiques sociales et mediations symboliques (pp. 23-44). Bern, Switzerland: Peter Lang.

Osorio, O. (2006). Siete estudios sobre la novela de la violencia en Colombia, una evaluación crítica y una nueva perspectiva. Poligramas, 25, 85-108.

Rocha, C. (2004). Escribir a oscuras: "El guerrillero" de Albalucía Ángel y "El lugar de su quietud" de Luisa Valenzuela. El cuento en red, 9, 18-30.

Salgado, J. (2008, August). Analysis of the text "The guerrillero" written by Albalucia Ángel. Paper presented at The 5th International Conference for the Dialogical Self, Cambridge, UK.

Simão, L. M. (2003). Beside rupture - disquiet; beyond the other - alterity. Culture \& Psychology, 9(4), 449-459.
Simão, L. M. (2008, August). Felicidad's challenge, a challenge to us. Paper presented at The 5th International Conference for the Dialogical Self, Cambridge, UK.

Valsiner, J. (1997). Dialogical models of psychological processes: capturing dynamics of development. Polish Quarterly of Developmental Psychology, 3(2), 155-160.

Valsiner, J. (2008, August). The Self Surrounding Itself: Double dialogicality. Paper presented at The 5th International Conference for the Dialogical Self, Cambridge, UK.

Voloshinov, V. N. (1976). Discourse in life and discourse in art (concerning sociological poetics). In V. N. Voloshinov, Freudianism: a marxist critique (I. R. Titunik, trans., pp. 93-116). New York, NY: Academic Press. (Trabalho original publicado em 1926)

Vygotsky, L. S. (1991). El significado histórico de la crisis de la psicología. Una investigación metodológica. In L. S. Vygotsky, Obras escogidas I (J. M. Bravo, trad., pp. 257-416). Madrid, Spain: Visor Distribuiciones. (Trabalho original publicado em 1927)

Vygotsky, L. S. (2001). Pensamiento y lenguaje. In L. S. Vygotsky, Obras escogidas II (J. M. Bravo, trad., pp. 9-348). Madrid, Spain: A. Machado Libros. (Trabalho original publicado em 1934)

Wagoner, B. (2008, August). The dialogical flow of emotions in "El guerrillero". Paper presented at The 5th International Conference for the Dialogical Self, Cambridge, UK.

Wagoner, B., Gillespie, A., Valsiner, J., Zittoun, T., Salgado, J., \& Simão, L. M. (2011). Repairing ruptures: multivocality of analyses. In M. Märtsin, B. Wagoner, E.-L. Aveling, I. Kadianaki \& L. Whittaker (Eds.), Dialogicality in focus: challenges to theory, method and application (pp. 105-127). Hauppauge, NY: Nova Science Publishers, Inc.

Wertsch, J. (1993). Voices of the mind: a sociocultural approach to mediated action. Cambridge, MA: Harvard University Press.

Williams, R. L. (1990). Albalucía Ángel. In D. E. Marting, Spanish American women writers (pp. 31-40). Westport, WA: Greewood press.

Wundt, W. (1924). The laws of psychical life. In W. Wundt, An introduction to psychology (pp. 154-198). London, UK: George Allen and Unwin (Trabalho original publicado em 1912)

Zittoun, T. (2008, August). A fight with an angel. Paper presented at The 5 th International Conference for the Dialogical Self, Cambridge, UK.

Received: January 20, 2015

Reviewed: March 22, 2016

Accepted: April 26, 2016 